Logos Universality Mentality Education Novelty, Section: Social Sciences

ISSN: $2284-5747$ (print), ISSN: $2284-5747$

(electronic)

Covered in: CEEOL, Index Copernicus, Ideas

$\mathrm{RePeC}$, EconPapers, Socionet

\title{
MIGRATION AND RELIGION IN ROMANIA: A STUDY REGARDING THE INFLUENCE OF MIGRATION BEHAVIOUR ON RELIGION
}

\author{
Alexandra Georgiana PARASCA \\ Andreea MORARU
}

Logos Universality Mentality Education Novelty, Section:

Social Sciences, 2014, Year III, Issue 1, pp: 119-128

Published by:

Lumen Publishing House

On behalf of:

Lumen Research Center in Social and Humanistic Sciences 


\title{
Migration and Religion in Romania: A Study Regarding the Influence of Migration Behaviour on Religion
}

\author{
Alexandra Georgiana PARASCA ${ }^{1}$ \\ Andreea MORARU ${ }^{2}$
}

\begin{abstract}
Through this article we try to capture another side of the migration, where the migratory behaviour contributes to obvious changes in the religious structure. Migration not only influences the accentuation of a religious diversity at a national, regional or local level, but it also creates a "religious mosaic", where, most often, conflicts appear, sign that humanity still has to work on its capacity of acceptance and celebration of differences. We can't talk about migration impact on religious life without making a reference regarding the level to which it is materialized; spatially, we can say that are several levels: national, regional and local.

The complexity of this social phenomenon provides us different perspectives of analysis and partial explanations concerning the present situation that Romania is facing. Under political, economic and cultural pressure, bumans react by searching and finding solutions for a better living, as migration in this case. Even if it is often seen as an economic privilege, migration cause major changes whose cyclical effects are manifested in social, demographic and economic aspects. While socio-economic impact of migration is well documented, the demographic impact and implicit religious impact is less studied.

Starting from the article title, it explains in a good measure the research direction of this paper which aims to facilitate the identification of disagreements on migration implications in religious sphere, situational awareness, a starting point for creating harmony, imperative actions in the era of globalization. To provide a visual image on the impact, we will also use the cartographic method.
\end{abstract}

\section{Keywords:}

Migration, religion, influence, Europe, Romania.

\footnotetext{
${ }^{1}$ Phd. Student, Alexandru Ioan Cuza University, Romania, alexandra_parasca@yahoo.com.

2Phd Student, Alexandru Ioan Cuza University, Romania, moraru.andreea@yahoo.com.
} 


\section{Introduction}

Population movement in search of a safer environment and better economic conditions is as old as human history. These movements not only profoundly affects the lives of migrants, but also lead to significant changes, demographic, economic and social, in migrants' countries of origin and in the destination ones. In his study of the Middle East and North Africa (MENA), Fargues (2006) argued that immigrants are "potential vectors for demographic change" and, in turn, Münz (2013) called migrants 'agents of change'. Migration is difficult to analyse: the process is complex, the data is poor and the theory is insufficient, says Coleman(2008). Certainly a study regarding the influence of migration on religion behaviour is more difficult especially when there is less accurate data on those two components at an international level, which is poorer in Romania.

If natural component affects religious structure through a reduction or increase in followers of religious confessions existing in a certain area as Brace et. all (2006) and Kong (2001) says, the migration often introduce other faiths inexistent previously, and thus a visible influence on the religious structure (Sotelo, 2010). These changes still appear different depending on the level at which they are examined, so that an analysis that starts from Europe continuing with a more accurate analysis over a smaller territory involving other types of borders, in this case Romania, will provide an image closer to reality in which they are embodied. The reason why the study begins with bringing in front the situation of European countries is to provide an overview of the situation in which Romania is, because while a population is open the migration is part of changes (de Haas, 2007a, 2007b), the religious structure is not excluded from this continuous process of transformation of a country (Surd, 1993) going through difficult times and where people saw migration as a relief and a chance for a better future.

\section{Migration and religion in Europe}

Lately, there has been a constant increase in international migration and international migration of temporary employment in European countries. An intense migration is recorded mainly in Western countries, particularly attractive countries. A current phenomenon is represented by countries of Central and Eastern Europe, which are not only countries of emigration, but have become immigration countries of transit and even become attractive mainly to migrant population in the Far East (Dumont, 1890/1990). While the population of Central Europe migrate to more developed countries of Western Europe, the 
same countries are countries of destination for migrants from Eastern Europe. If Western countries are characterized by a very active migration through a visible positive migration balance, as shown in Fig. 1, mainly eastern countries and southeast is characterized by a negative natural balance while the emigration exceeds immigration. North is represented by a less intense migration, but it is an area that is becoming increasingly attractive to residents of other countries who are seeking a better life. All this mobility is creating a "religious mosaic" never again so rich in diversity as in the current period (Rosendhal, 2002).

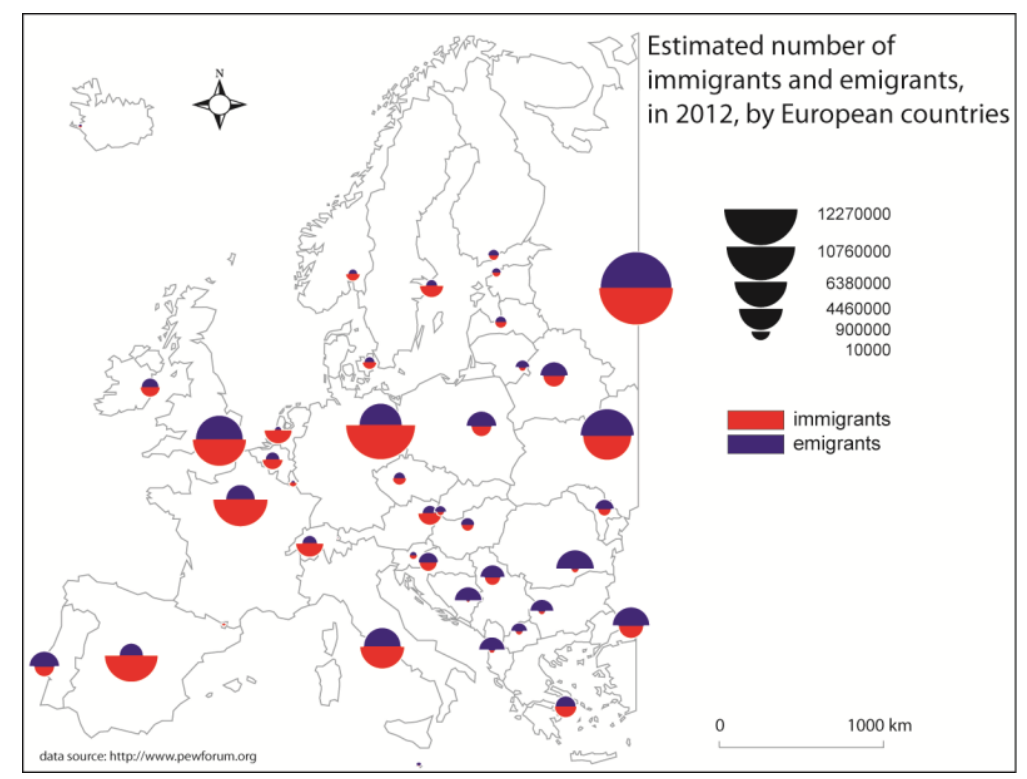

Fig.1. Estimated number of immigrants and emigrants, in 2012, by European countries

Looking at Fig. 2, it is clear that migration is higher for Christians, but we must keep in mind that this religion prevails in Europe (Piveteau, 1991). Emigrants stand out, while immigrants are in a smaller number. The largest number of Christian emigrants are in Russia and Ukraine and Germany, Russia, UK, Spain have a larger number of immigrants. Muslims, at a European level, stand out with a relatively large number of migrants, of whom predominantly immigrants in Britain, France, Germany, Spain, Italy. In the case of emigration, their numbers are very low. The main cause of immigration is the education, many of them wanting to have access at the best universities, but immigration is caused also because of other situations like civil wars, strict laws etc. 


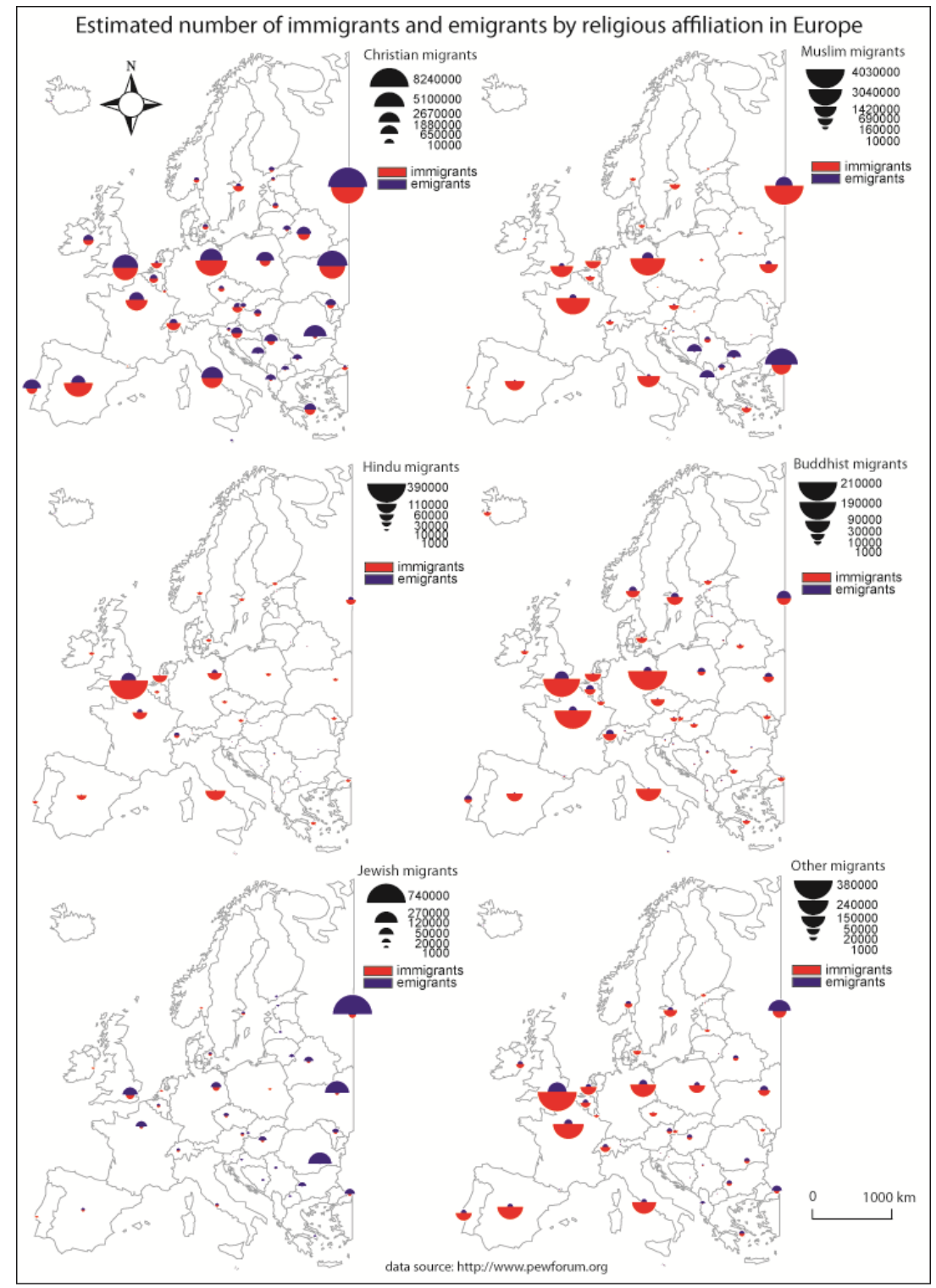

Fig.2. Estimated number of immigrants and emigrants by religious affiliation in Europe

Jews are characterized by a higher number of immigrants as main countries being Russia, Ukraine, Romania, United Kingdom, etc. Cause of emigration was definitely their desire to migrate to Israel, the "holy land", especially many young people attracted by economic opportunities ${ }^{1}$. Another reason is that they do not feel safe living in their countries, as there are still issues of anti-Semitism, issues of discrimination, acts of violence against Jews. 
Migration and Religion in Romania: A Study Regarding the Influence of (...) Alexandra Georgiana PARASCA, Andreea MORARU

Because of these reasons, they feel forced by circumstances to emigrate to a country where they feel accepted ${ }^{2}$.

\section{Migration and religion in Romania}

The 90 s were characterized by the disappearance of $40 \%$ of jobs in Romania, due to political disturbances, especially socio-economic, and the emergence of migration. Thus, after 1989, Romania lost population due to the return of the Germans, Hungarians and Jews in their countries of origin, migration based on visas traditional states of emigration-Canada, USA and Australia - the migration for education, for work under a contract or clandestine emigration subsequently transformed in definitive emigration, to countries such as Italy or Spain where migration had certain regulations, and since 2002 to the central and western Europe. Vasile Ghețău (2007) exonerated the states reaction claiming that migration phenomenon does not have negative consequences at an economic level. However, territorially, this phenomenon triggered a movement internally and externally for a number of people to regions or countries with a better economy which led to substantial changes, affecting also the religious structure, and leaving behind affected areas by a reduction in youth labour. If natural component affects only religious structure through a reduction or increase in the followers of denominations existing in the country, the migration often introduce other faiths previously inexistent, influencing the religious structure of Romania (Muntele, 2001-2002).

Relating with the results of population census in 1992, 2002 and 2011, most of the settlements present population reductions following a natural deficit and a negative migration balance. If 1990 and 1991 were revealing a rapid population decline on the grounds of major external migration, the following years were the direct product of the transition.

Regarding the migration balance in the counties of Romania, the south part of the country stand out through Bucharest, characterized by superiority to all counties and by recording a significant immigration starting with the 90s, immigration based initially on flows of repatriation. Bucharest manifests itself as a pole of attraction and it is apparent that most of the surrounding counties are inferior in this regard. Iaşi County also stand out as a second pole of attraction, but probably due to its proximity to the Republic of Moldova. In the last years it is noticed a slight increase of immigration in the country, the main "supplier" being the population from Republic of Moldova, China and Turkey. 


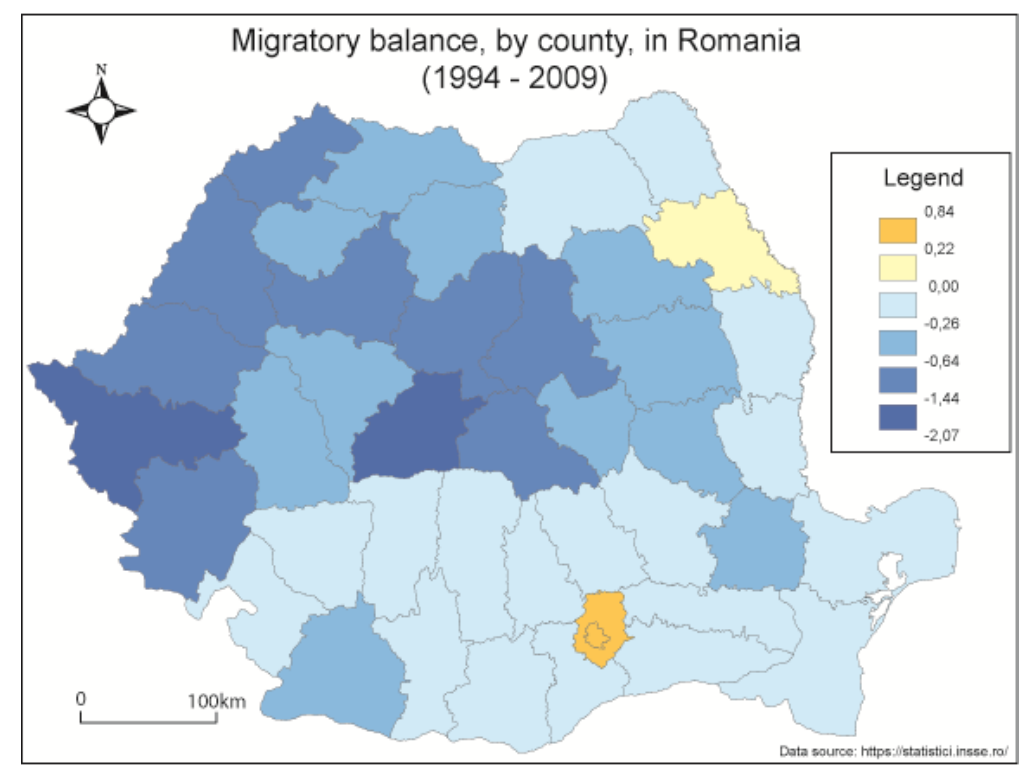

Fig.3. Migration balance, by county, in Romania (1994-2009)

Even though in recent years the number of immigrants increased, it is important to note that emigration exceeds immigration. Sibiu and Timis counties are characterized by the most representative Romanian emigration from the counties, but are followed from very close by other counties such as Cluj, Braşov, Mureş, Bacău, etc. Of course these are not the most worrying situation because of the significant benefits from immigration which creates a slightly positive balance. In addition to this there is also the advantage of universities which attract a representative number of young population.

Taking in count the statistical data registered to censuses from 1992, 2002 and 2011, we calculated in terms of increasing or decreasing the number of Orthodox and Catholic, by counties, to observe regional differences. Analysing the two cartographic representations, we can see that the number has decreased, both for Orthodox and Catholics. The main reason underlying this decrease is the "economic migration" of Romanians, over the last 20 years.

Number of Orthodox decreased more significantly compared to the number of Catholics, but considering the fact that Orthodox population represents majority in Romania this migration does not change the order. Regarding the decrease of the Orthodox religious community, the areas most affected by the decline are the counties of Galați, Prahova, Dolj, Bacău. Among Catholics, the most affected counties are Timiş, Bacău, Harghita, Arad, Neamț. However, in Bucharest, thanks to a positive migratory balance, is noted an increase among Catholic and Orthodox religious denominations. The number of Orthodox increased with about 68,000, while for Catholics number increased 
Migration and Religion in Romania: A Study Regarding the Influence of (...) Alexandra Georgiana PARASCA, Andreea MORARU

with 666 person. Should be noted that migration has a major influence on decreasing the number of followers of the two religions. Thus, we find that there is a direct link between the number of Orthodox / Catholic and migration.

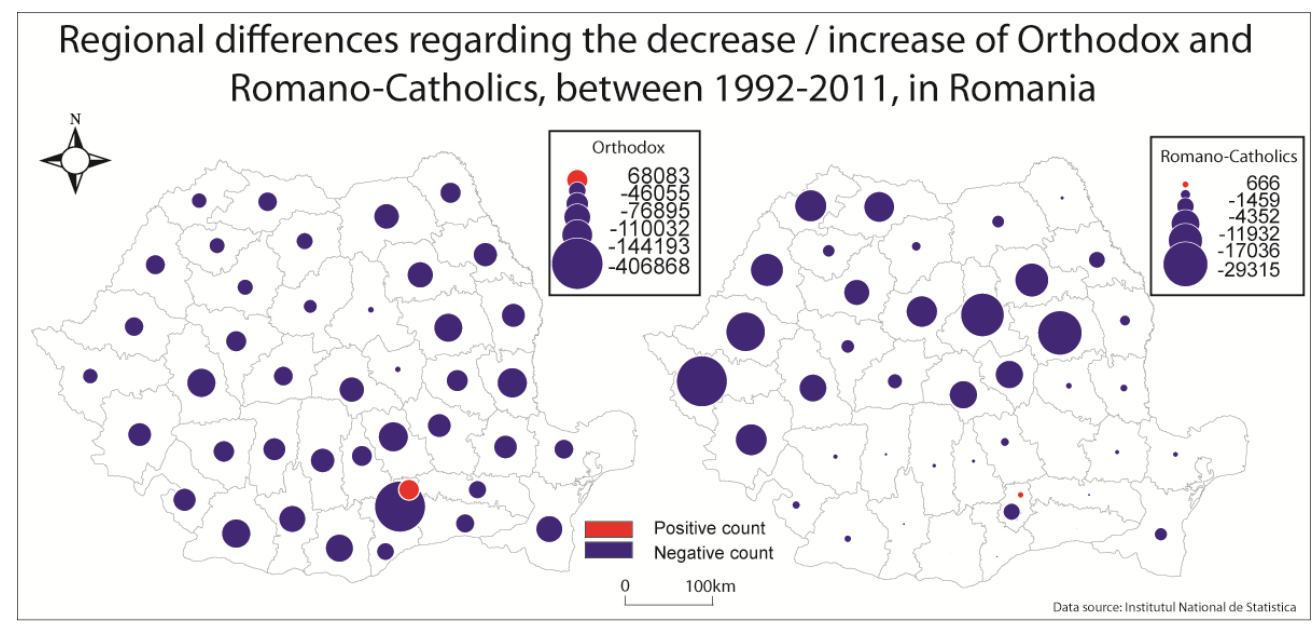

Fig.4. Regional differences regarding the decrease/increase of Orthodox and Romano-Catholics, between 1992-2011, in Romania

Regarding other religions, the situation is slightly different as we see in the table below. It can be noticed an increase among Pentecostals, with over 141,478 followers in the past 20 years. This is due to religious beliefs that encourage a high birth or a large family.

Tabel 1.Estimated number of decrease and increase of religious structure of population, in Romania

\begin{tabular}{|c|c|c|c|c|}
\hline $\begin{array}{c}\text { Confesiune } \\
\text { religioasă }\end{array}$ & $\begin{array}{c}\text { Recensământ } \\
1992\end{array}$ & $\begin{array}{c}\text { Recensământ } \\
2002\end{array}$ & $\begin{array}{c}\text { Recensământ } \\
2011\end{array}$ & $\begin{array}{c}\text { creşteri/ } \\
\text { descreşteri } \\
\text { estimate }\end{array}$ \\
\hline $\begin{array}{c}\text { Ortodocşi pe stil } \\
\text { vechi }\end{array}$ & 32228 & 27721 & 14381 & -17847 \\
\hline $\begin{array}{c}\text { Creştini de rit } \\
\text { vechi }\end{array}$ & 28542 & 29550 & 32557 & 4015 \\
\hline Greco catolici & 223368 & 191556 & 150593 & -72775 \\
\hline Reformați & 801473 & 701077 & 600932 & -200541 \\
\hline Luterani & 60287 & 35828 & 41076 & -19211 \\
\hline Unitarieni & 76693 & 66944 & 57676 & -19017 \\
\hline Armeni & 743 & 1805 & 382 & -361 \\
\hline Baptişti & 109568 & 126639 & 112850 & 3282 \\
\hline
\end{tabular}




\begin{tabular}{|c|c|c|c|c|}
\hline Adventişti & 77565 & 93670 & 80944 & 3379 \\
\hline Penticostali & 220836 & 324462 & 362314 & 141478 \\
\hline $\begin{array}{c}\text { Creştini după } \\
\text { evanghelie }\end{array}$ & 49954 & 62654 & 42495 & -7459 \\
\hline Mozaici & 9670 & 6057 & 3508 & -6162 \\
\hline Musulmani & 55928 & 66740 & 80377 & 24817 \\
\hline Altereligii & 55560 & 71668 & 80377 & 24817 \\
\hline Atei & 10331 & 8518 & 20743 & 10412 \\
\hline Fărăreligie & 24301 & 12817 & 18917 & -5384 \\
\hline
\end{tabular}

Data source: National Institute of Statistics

Muslims won another 8409 followers, follow by the old rite Christians, Baptists and Adventists which also increased their number. Muslim presence in Romania is ancient, the Dobrogea region being the one with the most followers. However, their number increased because of the Muslims coming to Romania for academic studies, and later settled here. Atheists number increased also with over 10000 followers. Following an investigation conducted by the Soros Foundation, it was concluded that atheists are "young, educated and intolerants"' ${ }^{3}$. Perhaps their number grew out because of a desire to differentiate themselves from the rest of the population or due to the fact that they don't even know exactly what the word atheist means.

High losses, in Romania, occurred among Calvinists, with the loss of over 200,000 followers. A significant loss for Greek-Catholics over 70,000 adherents, perhaps because during communism it was removed from the law, his property being confiscated. His followers suffered persecution at the time, the main purpose being to reduce the influence of the Catholic Church. Lutherans and Unitarians predominate among the Saxons, pointing out a decrease in rates. One of the reasons for this decline is the migration, as many of them are established in countries which offer a better economic future. Some of them, being by German origin, choose as destination Germany.

\section{Conclusions}

We can only reach the conclusion that the economic situation pushes Romanian people to choose as destinations other countries more developed, with several opportunities, searching a better chance in life. Thus, is directly affected the confessional structure of population, where it can be noticed religion followers fluctuation. We cannot say migration is the only cause, but we may say that migration is the main cause.

Concerning Europe, can be noticed that the number of Christians and Jews decreased, while the number of Buddhists, Hindus and Muslims increased. Christians tend to migrate more to USA, while the Jews migrate to Israel. 
Migration and Religion in Romania: A Study Regarding the Influence of (...) Alexandra Georgiana PARASCA, Andreea MORARU

Others migrate to Europe because of persecution, civil wars, religious conflicts, etc., to find a place where to feel safe. These are not the only reasons, lots of people choosing to live abroad also for the reason of a better job or even studies.

By this research over Romania, we found that migration exerts its influence on the number of followers of religions, their number decreasing or increasing. Unfortunately, the predominant case is decreasing the number of followers, growth being rarely found. The reasons why Romanians are determined to migrate are poverty, lack of financial resources, complaints about income, disparity between income and working conditions, lack of jobs or political imbalances, especially socio-economic imbalances and the list continue. We should be aware that the number of followers will still be down if Romania's situation will not change gradually.

Migration is a phenomenon that affects not only the religious structure of population, but also the economy, demography and society. Society should find solutions to stop this migration, providing professional development opportunities.

\section{REFERENCES}

Brace, C., Bailey, R., Harvey, D. (2006). Religion, place and framework, http://phg.sagepub.com/content/30/1/28

Coleman, D. (2008). The demographic effects of international migration in Europe. Oxford Review of Economic Policy, 24(3), 452-476.

Dumont, A. (1890/1990). Depopulation et civilisation: étude démographique. Paris: Economica.

de Haas, H. (2007a). Turning the tide? Why development will not stop migration. Development and Change, 38(5), 819-840.

de Haas, H. (2007b). Morocco's migration experience: a transitional perspective. International Migration, 45(4), 39-70.

Hecht, D. R. (2007). Active versus Passive Pluralism: A Changing Style of Civil Religion? The ANNALS of the American Academy of Political and Social Sciences, Iunie.

Fargues, P. (2006). The demographic benefits of international migration: a hypothesis and Its application to Middle Eastern and North African Countries. In C. Ozden \& M. Schiff (eds), International Migration, Economic Development and Policy, World Bank and Palgrave Macmillian, Washington DC.

Ghețău, V. (2007).Declinul demografic și viitorul populației României. O perspectivă din anul 2007 asupra populatiei României în secolul 21. Buzău: Academia Română, Ed. Alpha MDN. 
Kong, L. (2001). Mapping new geographies of religion: politics and poetics in modernity, http://phg.sagepub.com/content/25/2/211,

Münz, R. (2013). Demography and migration: an outlook for the 21st century. Migration Policy Institute, Policy Brief, no.4, Washington, 1-13.

Muntele, I. (2001-2002). Etnic şi confesional în dinamica naturală a populatiei României după 1966. Analele Universității de Vest din Timișoara, vol.XIXII, p. 217-228, Timişoara.

Piveteau, J. L. (1991). Territorialite europeenne et christianisme. Reflexion sur 1Europe. Economie si exchange: France, Allemagne, Europe Centrale. Revue Geographique de lEst, 3-4, pp.229-243.

Rosendhal, Z. (2002). Geographie et religion, Geographie et cultures. Religions et croyance no.42, 37 - 56, L"Harmatan, Paris.

Sotelo - Hondagneu, P. (2010). Immigration and Religion in America.Comperoray Sociology: A Journal of Reviews, 16 martie.

Surd, V. (1993). Ethnical and religious structure of the population in Romania. Geographica Timisiensis, vol. III, Timişoara, 109 - 118.

${ }^{1}$ http://www.jpost.com/Jewish-World/Jewish-News/Survey-29-percent-ofEuropean-Jews-considered-emigrating-due-to-anti-Semitism-331002

${ }^{2}$ http://www.nytimes.com/2014/06/21/world/europe/number-of-frenchjews-emigrating-to-israel-rises-sharply.html?_r $=0$

${ }^{3}$ http://www.fundatia.ro/ateii-din-rom $\% \mathrm{C} 3 \% \mathrm{~A} 2$ nia-putini-tineri-educati-dedreapta- $\%$ C $8 \% 99$ i-intoleranti 